\title{
COMPARISON OF SELECTION RESULTS IN ORGANIC AND CONVENTIONAL ENVIRONMENTS FOR WINTER TRITICALE
}

\author{
Arta Kronberga*, Linda Legzdina $a^{*}$, Vija Strazdiṇa**, and Zaiga Vicupe** \\ * State Priekuḷi Plant Breeding Institute, Zinātnes iela 1a, Priekuḷi, LV-4126, LATVIA; \\ Arta.Kronberga@ priekuliselekcija.Iv \\ ** State Stende Cereal Breeding Institute, Dižzemes, Dižstende, Libagu pag., Talsu nov., LV-3258, LATVIA; \\ vijastrazdina@inbox.Iv
}

Communicated by Edite Kaufmane

\begin{abstract}
One of key questions in breeding for organic agriculture is about most appropriate selection environment. A successful man-made cereal species, triticale (x Triticosecale Wittm. ex A. Camus.) - is very suitable for growing in organic crop management systems but little research has been conducted on breeding triticale for organic agriculture. Field trials were carried out in Priekuli during 2009-2012. One hundred $F_{4}$ winter triticale lines were sown in conventionally and organically managed fields. Selection of the approximately ten best lines in each environment, according to breeders' opinion with respect to suitability for organic conditions, was made. The selected lines were compared in both organic and conventional fields. The study did not show that there was a need to create varieties for organic farming by selection of triticale in the initial generations in organic fields.
\end{abstract}

Key words: triticale, selection environment, organic agriculture.

Breeding for organic agriculture is a relatively new breeding discipline and currently there are many questions, but not so many answers. One of the key questions in organic breeding is about determination of the best selection environment (Wolfe et al., 2008; Kirk et al., 2012). Two types of breeding programmes are used at present in breeding varieties for organic farming (Wolfe et al., 2008). The main differences between them are:

1. Breeding programmes for organic agriculture, where selection in first generations is done in conventional field, but testing of selected lines in later stages of breeding programme is performed in organic fields. One of the reasons for these breeding programmes is imposed by an economic factor: because of a small growing area for organic varieties, incomes from royalty cannot cover breeding expenses (Löschenberger et al., 2008). Other reason is that the expression of several traits can highly correlated under conventional and organic conditions (Oberforster et al., 2000; Dawson et al., 2007; Przystalski et al., 2008). Since it is not possible to evaluate part of traits which are important in organic conditions in the conventional field, some genotypes with specific suitability to organic conditions might be lost.

2. Breeding programmes for organic agriculture where all steps of the breeding process are carried out under organic growing conditions due to the genotype-environment interaction.

Research on selection environments have shown that breeding of varieties suitable for organic conditions should be carried out under organically managed land (Reid et al., 2009; Reid et al., 2010; Kirk et al., 2012). Taking into consideration that every species reacts on growing conditions in a different way, research results available on this topic are quite limited and on the basis of them it is not possible to clearly define a breeding strategy for all species.

A very successful man-made cereal species, triticale $(x$ Triticosecale Wittm. ex A. Camus.), is suitable for growing in organic fields due to its stable yield, tolerance to marginal conditions, resistance to diseases and high competitive ability against weeds. Due to high quality of grain, organically grown triticale has great potential: it can be used for human food and livestock feed (Green et al., 2002). Currently, organic fields contain triticale varieties that have been bred in conventional breeding programmes. There has been little research conducted to substantiate breeding of triticale for organic agriculture.

The aim of this study was to evaluate the most appropriate selection environment in initial generations of breeding winter triticale varieties for organic farming. 


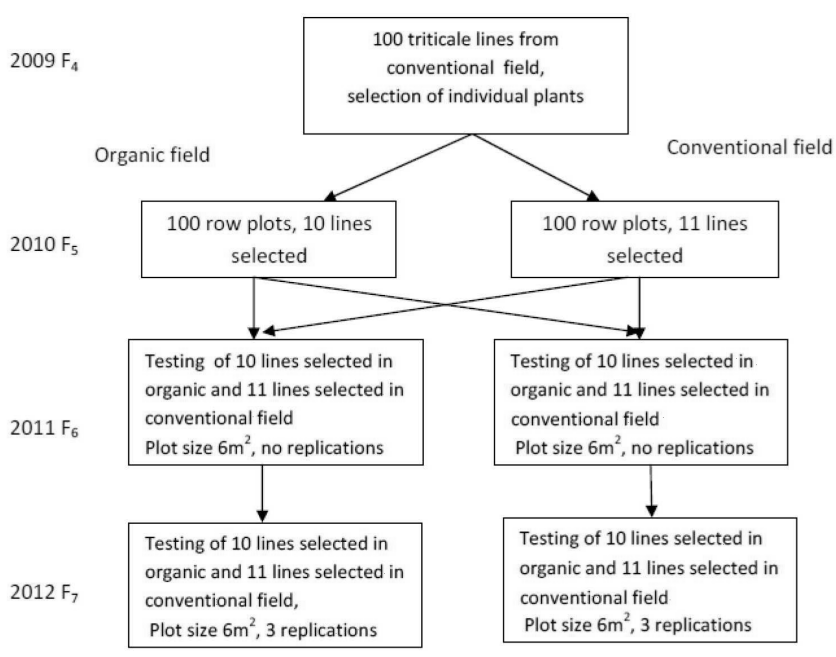

Fig. 1. Scheme of the winter triticale breeding experiment, Priekuli 2009-2012.

Field experiments were performed in organically and conventionally managed fields in Priekuli, $57^{\circ} 19^{\prime} \mathrm{N}, 25^{\circ} 20^{\prime} \mathrm{E}$. Selection in early generations was performed using pedigree method in conventional conditions (Fig. 1). One hundred $\mathrm{F}_{4}$ winter triticale lines with different pedigrees were chosen from conventional breeding material in 2009 and sown in conventionally and organically managed fields. In 2010, selection of approximately ten best lines in each environment, according to breeders' opinion with respect to suitability for organic conditions, was made. During the vegetation season in 2011 and 2012, the selected lines were compared in organic and conventional fields and different traits essential for organic conditions were evaluated.

In conventionally managed fields, complex mineral fertiliser was applied before cultivation: $\mathrm{N}-18, \mathrm{P}_{2} \mathrm{O}_{5^{-}}-78, \mathrm{~K}_{2} \mathrm{O}-90$ $\mathrm{kg} \mathrm{ha}^{-1}$, nitrogen fertiliser containing $\mathrm{N} 105 \mathrm{~kg} \mathrm{ha}^{-1}$ was applied in spring, as well as herbicide. The organic experiments were managed in fields certified for organic farming. Green manure was used as fertiliser in the organic crop rotation.

In autumn 2009, trial plots were sown manually in two 1$\mathrm{m}$-long rows per line, 20 seeds per row. Since the breeder has to perform selection in early breeding generations by evaluating separate plants or very small plots, the selection was mainly performed by visual scoring, taking into consideration traits that could be important for triticale in organic farming - winter hardiness ( 1 - very low, 9 - very high), canopy height (growth stage according to the Zadoks decimal scale (GS) - 31-32), soil shading (GS 31-32) (visually estimated area covered by plants, 1 - not covered, 9 - completely covered). In the growing season 2010-2011, the selected lines were sown in non-replicated $6 \mathrm{~m}^{2}$ plots with seeding rate 400 germinating seeds per $\mathrm{m}^{2}$. In growing season 2011-2012, trials were performed in plots of $6 \mathrm{~m}^{2}$ with three replications and the same seeding rate. Yield was calculated based on $14 \%$ grain moisture. Quality parameters (crude protein) were measured using an Infratec Grain Analyser (Foss) calibrated for triticale. Meteorological condi- tions in the years of the investigation varied significantly. Overwintering conditions in winter 2009/2010 were unfavourable: snow lasted for a long period of time, which promoted development of snow mould and some genotypes died. Selection was performed only from those lines that overwintered well. In winter of 2010/2011, triticale overwintered well, but in April and May precipitation was low and triticale hardly tillered, which negatively affected the yield. The weather conditions in June and July were close to long-term average indicators. Thus, yield triticale was average, and the amount of heat was favourable for protein accumulation in grain. In 2011/2012, triticale overwintered well. Average temperatures were generally normal for the time of the year, but precipitation exceeded the long-term average. In those conditions triticale had high yield, but protein content in grain was comparatively low.

Statistical analysis. Two-factor ANOVA with replications (in 2012) and without replications (in 2011), as well as the t-test were used for statistical analysis. Phenotypic correlation coefficients were calculated between estimated values in both management systems.

Performing selection of the same 100 triticale genotypes both in organic and conventional field, genotypes with good winter hardiness, good ability to cover soil, as well as good productivity of ear (visual scoring) were chosen. Ten breeding lines from organic growing conditions and 11 from conventional growing conditions were selected; six of them were selected in both organic and conventional fields.

In 2011, the average grain yield of the selected lines in the conventional field was two times higher than that in the organic field $(P<0.01)$ (Table 1). Comparing lines selected in organic and conventional environments, lines selected from

Table 1

AVERAGE TRAIT VALUES DEPENDING ON SELECTION LOCATION IN ORGANIC (ORG) AND CONVENTIONAL (CON) FIELDS, PRIEKULI, 2011-2012

\begin{tabular}{|c|c|c|c|c|}
\hline \multirow{2}{*}{$\begin{array}{c}\text { Selection } \\
\text { location }\end{array}$} & \multicolumn{4}{|c|}{ Testing location, year } \\
\hline & ORG, 2011 & CON, 2011 & ORG, 2012 & $\mathrm{CON}, 2012$ \\
\hline \multicolumn{5}{|c|}{ Grain yield, $\mathrm{t} \mathrm{ha}^{-1}$} \\
\hline Organic & 2.60 & 5.44 & 4.84 & 6.13 \\
\hline Conventional & 3.30 & 6.61 & 4.75 & 5.70 \\
\hline$P$-value & 0.119 & 0.008 & 0.739 & 0.439 \\
\hline \multicolumn{5}{|c|}{ Canopy height, cm (GS 31-32) } \\
\hline Organic & 25.2 & 23.7 & 20.1 & 24.2 \\
\hline Conventional & 26.2 & 25.0 & 19.7 & 24.7 \\
\hline$P$-value & 0.358 & 0.253 & 0.562 & 0.774 \\
\hline \multicolumn{5}{|c|}{ Thousand kernel weight, $\mathrm{g}$} \\
\hline Organic & 40.6 & 46.6 & 46.6 & 39.3 \\
\hline Conventional & 40.6 & 43.5 & 46.3 & 37.1 \\
\hline$P$-value & 0.998 & 0.179 & 0.869 & 0.289 \\
\hline \multicolumn{5}{|c|}{ Crude protein, g $100 \mathrm{~g}^{-1}$} \\
\hline Organic & 109.0 & 141.0 & 103.3 & 125.6 \\
\hline Conventional & 108.8 & 142.4 & 107.9 & 125.4 \\
\hline$P$-value & 0.946 & 0.658 & 0.151 & 0.963 \\
\hline
\end{tabular}


the conventional field had significantly $(P<0.01)$ higher average yield than those harvested from the organic field. Similar results were obtained for plant canopy: lines, selected in the conventional field were taller in 2011, but the difference between lines originating from organic and conventional conditions was not significant $(P>0.05)$. Samples from conventional field had higher 1000 kernel weight and protein content in grain, but the differences between lines selected in conventional and organic environments were not significant.

In 2012, average yield in conventional field was $22 \%$ higher than in conventional field, and the difference in yield levels was significant $(P<0.01)$. The yield, plant canopy height, 1000 kernel weight and protein content in grain depended on genotype and there were no significant differences between organically and conventionally selected lines $(P>$ $0.05)$.

Phenotypic correlation coefficients between evaluated traits in organic and conventional fields were significant and positive: for yield $\mathrm{r}=0.585(P<0.01), 1000$ kernel weight $\mathrm{r}=0.750(P<0.01)$, protein content in grain $\mathrm{r}=0.536(P<$ $0.01)$, plant canopy height $\mathrm{r}=0.828(P<0.01)$.

Considering the effect of the management system on next year's crop, yield of lines selected in different environments was compared only in 2012. Ten genotypes in the organic field were more productive than the average value of the trial, but there were only seven such genotypes in the conventional field (Table 2). The most productive lines in the organic field included three lines selected in the organic field, four lines in the conventional field, and four lines se-

Table 2

YIELD AND RANKING ACCORDING TO YIELD OF THE TRITICALE LINES, SELECTED IN ORGANIC (ORG), CONVENTIONAL (CON) OR BOTH (ORGANIC AND CONVENTIONAL) ENVIRONMENTS, 2012

\begin{tabular}{|c|c|c|c|c|c|}
\hline \multicolumn{3}{|c|}{ Organic management } & \multicolumn{3}{|c|}{ Conventional management } \\
\hline $\begin{array}{l}\text { Yield, } \\
\text { t ha }^{-1}\end{array}$ & Rank & Line & Line & Rank & $\begin{array}{l}\text { Yield, } \\
\text { t ha }^{-1}\end{array}$ \\
\hline 5.50 & 1 & ORG 0415-77 & -ORG 0415-77 & 1 & 7.72 \\
\hline 5.33 & 2 & ORG 0419-104 & ORG 0426-125 & 2 & 7.67 \\
\hline 5.28 & 3 & 0426-47 & ORG 0419-104 & 3 & 6.94 \\
\hline 5.17 & 4 & $0422-88$ & $0426-47$ & 4 & 6.67 \\
\hline 5.06 & 5 & CON 0422-26 & $22-59$ & 5 & 6.44 \\
\hline 5.00 & 6 & 0426-144 & $0422-26$ & 6 & 6.39 \\
\hline 5.00 & 7 & $0422-59$ & ○422-88 & 7 & 6.17 \\
\hline 4.94 & 8 & CON 0421-54 & Mean & & 5.90 \\
\hline 4.89 & 9 & ORG 0426-125 & -0426-144 & 8 & 5.67 \\
\hline 4.83 & 10 & CON 0415-3 & CON 0421-60 & 9 & 5.39 \\
\hline 4.79 & & Mean & $0421-23$ & 10 & 5.22 \\
\hline 4.61 & 11 & $0421-23$ & 0419-91 & 11 & 5.11 \\
\hline 4.39 & 12 & CON 0421-92 & CON 0415-3 & 12 & 4.61 \\
\hline 4.39 & 13 & CON 0421-60 & CON 0421-54 & 13 & 4.06 \\
\hline 4.00 & 14 & 0419-91 & CON 0421-92 & 14 & 3.67 \\
\hline 3.61 & 15 & ORG 0421-107 & ORG 0421-107 & 15 & 3.67 \\
\hline
\end{tabular}

lected in both fields. The most productive in the conventional field were three lines selected from organic conditions, one from conventional, and three from both conditions. Therefore, the effect of selection environment was unclear and it could not be clearly stated which provided better results in order to select genotypes for organic conditions.

Selection in early generations of breeding usually is performed by selecting one plant or small plot. In such smallsize plots a great part of traits cannot be measured precisely; plants are being evaluated by phenotypically well-seen traits. Therefore, the result of selection depends more on breeder's experience and one's imagined variety model than of selection location. Phenotypically stable and easily measurable visual traits were used as selection criteria for triticale. This affected also the results, since selection outcome was very similar from both management systems: the larger part of the selected genotypes were the same when selected in organic and conventional fields. The main reason why some selected genotypes differed between the fields could be due to their winter-hardiness (depending on soil microtopography), which further affected growth of lines and development during the period of vegetation.

In 2011, genotypes selected in the conventional field showed greater yield both in organic and conventional growing conditions. This difference between organically and conventionally selected lines was not observed in 2012. Seed quality and vigour are affected by agrometeorological conditions at grain ripening time (Muasya et al., 2008). Since the meteorological conditions in both trial locations of the current research were identical, plant growth and development was mostly affected by growth conditions: genotypes grown in the organic field did not receive sufficient amounts of nutrients, and therefore, could not provide the high yields in next year of plants in the conventional field. After a year, the yield was similar between lines selected both in conventional and organic conditions, as was expected since environmental growing conditions of the parent can influence seed performance (Kristensen, 2003). This factor must be taken into consideration during the breeding process: in the first year of trials in organic conditions, it would not be correct to compare yield of genotypes, which in the previous year were grown in different growth conditions.

Although plant canopy in stem elongation stage was one of the traits taken into consideration during the selection process, there was no significant difference between organically and conventionally selected lines, neither in 2011, nor in 2012. Plant height has high heritability, depending on genotype (Nanda et al., 1981), which can explain why we found no difference between crop management system. Other analysed traits, such as 1000 kernel weight and protein content, did not significantly differ between conventionally and organically selected lines in any of the trial years; those traits were not used as criteria in the selection process. 
Though the phenotypic correlation coefficient between yield in organic and conventional field was significant, it was comparatively low, indicating the necessity to evaluate separate genotypes and their suitability specifically for organic conditions. Yield of genotypes selected in organic and conventional fields was similar (Table 2), but some genotypes showed effect of growth conditions. Lines selected in organic conditions had the highest yield in both testing environments. The highest yield in both organic and conventional field was obtained from a line selected in organic conditions. Line 0426-125, which was selected in the organic field, demonstrated the second highest yield in the conventional field, but was only in ninth place in the organic field. Some genotypes were more productive in organic conditions, but their yield in conventional trials was below average. The selection was made in a year when winter was very unfavourable for triticale overwintering, and allowed to select only genotypes with good winter-hardiness. After poor overwintering, triticale genotypes cannot demonstrate their yield potential. However, evaluation of the selected genotypes was performed in a year when triticale had good winterhardiness, and then it was possible to evaluate and select genotypes with good yield potential.

The study did not clearly demonstrate whether early generation selection for breeding of triticale varieties for organic farming should be performed in organic or conventional conditions. Taking into account that in early stages of breeding individual plants or small plots are being selected and visual scoring of only few traits with good phenotypic expression can be performed, selection of triticale can be carried out in the frames of conventional breeding programmes as well.

This study was performed with financial support of European Social Fund co-financed project "Development, Improvement and Implementation of Environmentally Friendly and Sustainable Crop Breeding Technologies" 2009/0218/1DP/1.1.1.2.0/09/APIA/VIAA/099.

\section{REFERENCES}

Dawson, J. C., Murphy, K. M., Jones, S. S. (2007). Decentralized selection and participatory approaches in plant breeding for low-input systems. Euphytica, 160, 143-154.

Green, C., Arseniuk, E., Osinski, R. (2002). The competitive position of triticale in Europe. Proceedings of the 5th International Triticale Symposium, Radzików, Poland, 30 June - 5 July, 2002. Volume I: Oral Presentations. Plant Breeding and Acclimatization Institute.

Kirk, A. P., Fox, S. L., Entz, M. H. (2012). Comparison of organic and conventional selection environments for spring wheat. Plant Breed. 131 (6), 687-694.

Kristensen, L. (2003). Maternal effects due to organic and conventional growing conditions in spring barley (Hordeum vulgare). Biol. Agricult. Hort., 21, 195-208.

Löschenberger, F., Fleck, A., Grausgruber, H., Hetzendorfer, H., Hof, G., Lafferty, J., Marn, M., Neumayer, A., Pfaffinger, G., Birschitzky, J. (2008). Breeding for organic agriculture: The example of winter wheat in Austria. Euphytica, 163, 469-480.

Muasya, R. M., Lommen, W. J. M., Muui, C. W., Struik, P. C. (2008). How weather during development of common bean (Phaseolus vulgaris L.) affects the crop's maximum attainable seed quality. NJAS - Wageningen J. Life Sci., 56,85-100.

Nanda, G. S., Hazarika, G. N., Gill, K. S. (1981). Inheritance of heading date, plant height, ear length and spikelets per spike in an intervarietal cross of wheat. Theor. Appl. Gen., 60, 167-171.

Oberforster, M., Plakolm, G., Söllinger, J., Werteker, M., Alföldi, T., Lockeretz, W., Niggli, U. (2000). Are descriptions of conventional variety testing suitable for organic farming? IFOAM 2000: The World Grows Organic. Proceedings 13th International IFOAM Scientific Conference, Basel, Switzerland, 28 to 31 August, 2000., vdf Hochschulverlag AG an der ETH Zurich.

Przystalski, M., Osman, A., Thiemt, E. M., Rolland, B., Ericson, L., Østergård, H., Levy, L., Wolfe, M., Büchse, A., Piepho, H.-P., Krajewski, P. (2008). Comparing the performance of cereal varieties in organic and non-organic cropping systems in different European countries. Euphytica, 163, 417-433.

Reid, T. A., Yang, R.-C., Salmon, D. F., Navabi, A., Spaner, D. (2010). Realized gains from selection for spring wheat grain yield are different in conventional and organically managed systems. Euphytica, 177, 253-266.

Reid, T. A., Yang, R.-C., Salmon, D. F., Spaner, D. (2009). Should spring wheat breeding for organically managed systems be conducted on organically managed land? Euphytica 169, 239-252.

Wolfe, M. S., Baresel, J. P., Desclaux, D., Goldringer, I., Hoad, S., Kovacs, G., Löschenberger, F., Miedaner, T., Østergård, H., Lammerts van Bueren, E. T. (2008). Developments in breeding cereals for organic agriculture. Euphytica, 163, 323-346.

\section{IZLASES REZULTĀTI KONVENCIONĀLAJOS UN BIOLOG̣ISKAJOS AUDZĒŠANAS APSTĀKLOSOS ZIEMAS TRITIKĀLEI}

Selekcijā biologíiskajai lauksaimniecībai viens no svarīgākajiem jautājumiem ir, vai izlasi nepieciešams veikt bioloğiskajos apstākḷos vai to var veikt arī konvencionālās selekcijas programmā. Par šo jautājumu pētījumi veikti loti maz, praktiski vispār nav pētīta tritikāle $(x$ Triticosecale Wittm. ex A. Camus.) — graudaugu suga, kas ir ḷoti piemērota audzēšanai bioloǵiskajos apstākḷos, jo spēj efektīvi izmantot augsnē esošās barības vielas. Pētîjuma mērḳis bija izvērtēt izlases efektivitāti agrīnajās selekcijas paaudzēs, lai veidotu ziemas tritikāles škirnes bioloǵiskajai lauksaimniecībai. Lauka izmēǵinājumi iekārtoti Valsts Priekuḷu laukaugu selekcijas institūtā no 2009. gada lỉdz 2012. gadam. 100 tritikāles līnijas paralēli iesētas bioloǵiskajā un konvencionālajā laukā un katrā atlasītas apmēram desmit pēc selekcionāra vērtējuma piemērotākās bioloǵiskajai lauksaimniecībai. Atlasītās līnijas vērtētas bioloğiskajos un konvencionālajos apstākḷos. Izmēǵinājumā netika pierādīts, ka, veidojot škirnes bioloğiskajai lauksaimniecībai, tritikālei pirmajās paaudzēs izlase jāveic bioloğiskajā laukā. 